\title{
Training Social Information Processing in Elementary School Children With Intellectual Disabilities: A Key to Support Their Emotion Regulation and Social Behaviors
}

\author{
Emilie Jacobs ${ }^{1}$, Nathalie Nader-Grosbois ${ }^{1}$ \\ ${ }^{1}$ Psychological Sciences Research Institute, Chair Baron Frère in special education, UCLouvain, Belgium \\ Correspondence: Nathalie Nader-Grosbois, Psychological Sciences Research Institute, UCLouvain, 10 Place Cardinal \\ Mercier, 1348 Louvain-la-Neuve, Belgium.
}

Received: Jan. 9, 2020

Accepted: Mar. 26, 2020

Online Published: May 5, 2020

doi:10.11114/jets.v8i6.4840

URL: https://doi.org/10.11114/jets.v8i6.4840

\begin{abstract}
Children with intellectual disabilities (IDs) show deficits in social information processing (SIP) that increased the risk of social maladjustment. As social inclusion is a major preoccupation for professionals and parents, it is important to know how foster SIP among these children, in order to support their understanding of social situations, their emotion regulation and social adjustment. The present study tested the efficacy of a new "SIP program for children", considering specific strengths and weaknesses of these children. It also explored the potential causal contribution of SIP in elementary school children with ID to their emotion regulation, social adjustment and internalizing and externalizing behaviors. 30 children between 5 and 12 years with mild or moderate IDs, took part in a pre-test session involving measures on cognition and social problem solving. Teachers and/or parents completed questionnaires assessing children's emotion regulation and social adjustment. Secondly, children were allocated to control or experimental groups. Experimental group participated in the "SIP program for children". It was implemented by two trainers which used the specific material and technics described by the program during eight sessions to sub-groups of three children. After, all children took part in post-test sessions. Results showed significant improvement of social problem-solving abilities in children of experimental groups. After SIP training, they easily judged social behaviors and produced more complex justifications related to social consciousness and social rules, in comparison to the control group. Parents perceived children who had participated in the training as more socially adjusted and teachers described them as more integrated, autonomous and cooperative. These children were also perceived as displaying fewer internalizing problems.
\end{abstract}

Keywords: social information processing, social problem solving, training, intellectual disabilities, emotion regulation, social adjustment

\section{Introduction}

For the last ten years, abilities and deficits in social information processing (SIP) have been studied in populations with intellectual disabilities (IDs), in order to explain how the risk of behavior disorders develops (van Nieuwenhuijzen et al., 2006). Researches underlined a higher risk for children with IDs to display some externalized (Taylor, 2002) or internalized behavioral problems (Merrell \& Holland, 1997; Thirion-Marissiaux \& Nader-Grosbois, 2008), or even both (Baker et al., 2003; Dekker \& Koot, 2003; Dekker, Koot, Ende, \& Verhulst, 2002; Emerson, 2003; Nader-Grosbois, Houssa, \& Mazzone, 2013). Externalized behaviors are described as aggressiveness, impulsivity, agitation, disobedience or opposition while internalized behaviors are related to anxiety, depression, dependence and isolation. The SIP model was originally elaborated by Crick and Dodge (1994) to understand aggressive behaviors and to detect which SIP steps are deficient in children without intellectual disabilities but displaying externalizing behavior disorders (dodge,2014). This theoretical conception described five cognitive steps -encoding of social cues, interpretation, goal clarification, response generation and response selection - leading to social behavior (Crick \& Dodge, 1994; Rubin \& Krasnor, 1986). The successful completion of these steps leads children to behave in socially adaptive way. Several recent studies have shown the efficacy of training focusing on SIP for children of preschool and school age at risk of externalizing behavior. Such training improves social adjustment and decreases behavior problems (Houssa, Jacobs, \& Nader-Grosbois, 2016; Houssa, Volckaert, Nader-Grosbois, \& Noël, 2017; Shure, 1993; Webster-Stratton \& Hammond, 1997). Other studies have also reported positive effects of SIP training for children with autism spectrum disorders, with 
and without IDs (e.g. Bernard-Opitz, Sriram, \& Nakhoda-Sapuan, 2001; Radley, Ford, Battaglia, \& McHugh, 2014). However, few studies have specifically examined the characteristics of SIP in social situations in children with IDs functioning at preschool developmental age. There has been little experimental research testing the efficacy of SIP training for this population and investigating whether SIP deficits could be a causal factor of social maladjustment. Which SIP deficits are emphasized in children with IDs and are related to social (mal)adjustment?

In social problem-solving, children with IDs struggle to encode (step 1) and to interpret social and emotional cues (step 2), especially negative ones (van Nieuwenhuijzen, Orobio de Castro, Wijnroks, Vermeer, \& Matthys, 2004; van Nieuwenhuijzen, Orobio de Castro, Wijnroks, Vermeer, \& Matthys, 2009). Negative cues are related to ambiguous social situations or provocation. Concretely, difficulties result from the faulty detection of information related to negative events and from a misidentification of cues indicating unintentional actions. Therefore, children with IDs are more likely to attribute hostile intentions to others (Jahoda, Pert, \& Trower, 2006; van Nieuwenhuijzen \& Vriens, 2012). However, they show no difficulty when cues reveal clearly hostile intentions (Crick \& Dodge, 1994; Leffert, Siperstein, \& Millikan, 2000). Difficulties in the first two steps of SIP lead children to evaluate assertive responses as suitable and to produce aggressive reactions (steps 4 and 5) (Leffert \& Siperstein, 1996; van Nieuwenhuijzen et al., 2009; van Nieuwenhuijzen \& Vriens, 2012). Jacobs, Simon and Nader-Grosbois (Submitted) investigated SIP profiles of elementary school children with IDs displaying a developmental age between 3 and 7 and half. Their results indicated that children with higher verbal developmental age identified more easily if the protagonist's social behavior is appropriate or inappropriate, in critical social situations and they justified easier in considering the intersubjective relationships between protagonists, or in referring to social rules to judge whether a protagonist displayed appropriate or inappropriate behavior towards the other protagonist. However, these children with IDs showed more difficulties in negative social situations than in positive ones.

These SIP deficits could explain social difficulties (van Nieuwenhuijzen et al., 2009; van Nieuwenhuijzen \& Vriens, 2012) and affect emotion regulation, social maladjustment or the risk of behavioral problems (Baurain \& Nader-Grosbois, 2013; Leffert \& Siperstein, 1996; van Nieuwenhuijzen et al., 2004). Such maladaptive behaviors in turn affect social competences and autonomy (Crnic, Hoffman, Gaze, \& Edelbrock, 2004; Keogh, Bernheimer, Daley, \& Haney, 1989; Merrell \& Holland, 1997; Zion \& Jenvey, 2006). Concretely, by being resistant to others, children with IDs experience less cooperative or prosocial behaviors during social interaction (Kasari \& Bauminger, 1998). Their anxiety limits social integration. They tend to depend on others, especially their parents, which reduces their autonomous behaviors. Adolescents with IDs are more likely to have feelings of solitude, isolation, rejection and social dissatisfaction than typically developing children (Gascon, Bibeau, Grondin, \& Milot, 2010). Concerning their emotion regulation abilities, children with IDs display a delay in the development of this competence (Baurain \& Nader-Grosbois, 2012; Nader-Grosbois et al., 2013) and struggle to regulate their emotions particularly in situations inducing frustration, delay of gratification, or provocation (Baurain \& Nader-Grosbois, 2013). These observations underline the importance of working with children with IDs to foster social inclusion. Yet, could SIP training be adapted and efficient for children with a lower intellectual quotient? Some studies have already examined the effects of SIP training in children with developmental disorders. What findings reported in studies about SIP training could be helpful for designing training adapted to children with IDs?

A few SIP training programs have been developed for adolescents and adults with IDs (Anderson \& Kazantzis, 2008; Cote, 2011; Crites \& Dunn, 2004; Nestler \& Goldbeck, 2011; O’Reilly et al., 2004; Vlachou \& Stavroussi, 2016). Yet, most SIP programs have been implemented among children with externalizing behaviors at preschool and school age (for a review see Houssa, 2016; Houssa et al., 2016; Houssa et al., 2017); and some among children with autism spectrum disorder, with or without IDs (Bernard-Opitz et al., 2001; Radley et al., 2014). Such programs aim to help children to solve social problems, to distinguish benign or hostile intentions in critical social situations and to find the most appropriate behavioral response. The main materials used are videos, pictures, games and books illustrating critical social situations. During sessions with participants, experimenters discuss and ask questions about social and emotional cues, how they should be interpreted and about alternative responses. They usually give immediate and individual feedback. The steps in the social problem-solving process and appropriate responses are underlined by means of key concepts (Anderson \& Kazantzis, 2008; Bernard-Opitz et al., 2001; Crites \& Dunn, 2004; Houssa et al., 2016; Nader-Grosbois, Houssa, Jacobs, \& Mazzone, 2016; Nestler \& Goldbeck, 2011). The training has positive effects on the participants' social problem-solving competences: for instance, they identify and interpret social cues more easily, and they tend to select socially adaptive responses. SIP skills are usually generalized to new social situations. The results of the few studies evaluating broader effects indicate better social adjustment, less maladjustment and fewer behavior disorders in participants, and lower levels of stress or depression in their parents. Very few of these studies involved the use of SIP training for younger children with IDs, compared the effects with a control group, tested the effectiveness on SIP steps, or examined the causal contribution of SIP on children's social adjustment or emotion regulation. Given these 
gaps, the present study tested the effectiveness of a specific training, namely the "SIP program for children", in elementary school children with mild to moderate IDs. The objective was to improve social problem-solving abilities, emotion regulation and social adjustment. To evaluate the effects, we compared abilities in these domains among children who participated in this program to those of a control group, by pre- and post-tests sessions. It was hypothesized that the "SIP program for children" would (1) help children to use more efficiently steps of SIP process, such as identifying relevant social and emotional cues, judging whether behaviors displayed by protagonists in hypothetical social situations was appropriate or not, and justifying their choices; and (2) would support a better emotion regulation and social adjustment.

\section{Methods}

\subsection{Participants}

The 30 children (17 boys and 13 girls) were recruited from specialized primary schools in French-speaking areas of Belgium. They presented a mean age of 109.87 months $(S D=20.94)$, ranging from 67 to 150 months, and IQs between 50 and 70. They displayed a non-specific intellectual disability and a global developmental age (GDA) of 63.18 months (SD $=14.05$ ), ranging from 44 to 88 months. These children had been diagnosed as having mild to moderate IDs. Children with Williams' syndrome or autistic spectrum disorder were excluded. The recruitment and the sample were restricted due to very strict inclusion criteria, the conditions of consent by schools, teachers and parents, notably for their approval of video recording, the need for participants to attend each session of training, and the requirement that both parents and teachers complete questionnaires at pre- and post-test. Moreover, some participants $(n=14)$ left the research program in progress, because some parents found that the completion of questionnaires took too much time and one school interrupted their collaboration for organizational reasons.

\subsection{Measures}

\subsubsection{Wechsler Preschool And Primary Scales (WPPSI-III; Wechsler, 2004)}

In the pre-test session, four subtests of WPPSI-III assessed verbal and non-verbal cognitive functioning and the global developmental age of each child: "information", "vocabulary", "block design" and "matrix reasoning".

\subsubsection{Problem-Solving Task (RES, Barisnikov, Van der Linden, \& Hippolyte, 2004)}

The problem-solving task estimates how children understand a protagonist's good or bad behavior in fictitious critical social situations, illustrated by 14 cards ( 9 with bad behaviors and 5 with good behaviors). It mobilizes SIP skills and evaluates children's capacity to judge a behavior as appropriate or not (judgment score), to identify target behavior with social cues (identification score), and to justify their judgment (justification score). To assess the judgment and the identification of critical behavior, experimenter asked the child "Is it good or bad" and "Could you indicate what is good or bad?", respectively. These two questions indicated if the child perceived and interpreted social cues well. The justification score is determined by the extent to which children base their response on the consequence for the protagonist (descriptive level: 2 points), on their social consciousness (intersubjective level: 5 points), or on reference to social rules (conventional level: 7 points). It is possible to distinguish scores related to appropriate or inappropriate cards. The maximum total score is 140: 28 for judgment, 14 for identification and 98 for justification. The validation was performed with typically developing children and children with IDs and revealed an inter-judge agreement of $98 \%$ (Hippolyte, Iglesias, Van der Linden, \& Barisnikov, 2010). For the present sample, the alpha was .84 and attested the reliability.

2.2.3 Emotion Regulation Checklist -French version (ERC; Nader-Grosbois \& Mazzone, 2015; Shields \& Cicchetti, 1997)

The parents completed this questionnaire assessing their perception of their children's emotion regulation or dysregulation. Positive emotion regulation is estimated through 8 items, referring to appropriate empathy, affective displays, and emotional and frustration control. For emotion dysregulation, 16 items reflect mood lability, angry reactivity or dysregulated negative affect. Using a 4-point Likert scale, from "never" to "almost always", parents estimate the occurrence of a described behavior. Three scores are obtained: emotion regulation and dysregulation scores, and a composite emotion regulation score (maximum 4). This measure is applicable for children aged from 3 to 12 years old, with or without development disorder. The factor analysis for the French version of this questionnaire confirmed two factors, namely "emotion regulation" and "emotion dysregulation". The inter-judge agreement was $88 \%$ for emotional regulation and $86 \%$ for emotional dysregulation. Cronbach's alpha was .70 and .61 for the present sample.

\subsubsection{Social Adjustment Scales for Children (EASE; Hughes, Soares-Boucaud Hochman \& Frith, 1997)}

This questionnaire assesses adults' perception of their children's social adjustment. Parents estimate for 50 items the frequency of a behavior in daily interactions, using 0,1 or 2 to indicate rare or missing, relatively frequent and usual 
respectively. Half of the items measure social skills, such as politeness, discipline or civility, and the other half of the items evaluate skills related to Theory of Mind abilities, such as taking into account others' emotions, desires or beliefs. The maximum total score is 100 . The two subscales have a good internal consistency, with Cronbach's alphas of .77 and .79 respectively (Hughes, Soares-Boucaud, Hochmann, \& Frith, 1997). In the present study, Cronbach's alpha was .93 for the whole scale.

\subsubsection{Social Competence and Behavior Evaluation scale (SCBE; LaFrenière, Dumas, Capuano, \& Dubeau, 1992)}

This questionnaire assesses children's social competence and maladjustment profile through 80 items. Parents evaluate to what extent their children display each behavior, using a 6-point Likert scale, from "never" to "always". The questionnaire provides a complete profile on eight socio-affective domains: angry-tolerant, anxious-secure, depressive-happy, isolated-integrated, dependent-autonomous, resistant-cooperative, egoistic-prosocial and aggressive-controlled. Each dimension is evaluated on a continuum, on the basis of information on the child's weakness and strengths in his or her socio-affective profile and in interactions with peers or adults. The eight dimensions can be combined into four global scales: general adjustment, social competences, externalizing problems and internalizing problems. The externalizing scale clusters the four dimensions angry-tolerant, resistant-cooperative, egoistic-prosocial and aggressive-controlled, while the internalizing scale brings together the four others (anxious-secure, depressive-happy, isolated-integrated, dependent-autonomous). When the scores are transformed into T-scores, difficulties or strengths on these scales can be identified. T-scores below 38 or above 68 reflect scores that are lower or higher than the mean scores observed in a representative sample. For the French version, the eight subscales display Cronbach's alphas of between .79 and .82 and for the present sample between .78 and .88 .

\subsubsection{Child Behavior Checklist (CBCL; Achenbach, 1991)}

This well-known questionnaire of 79 items assesses parents' perception of children's behavioral and emotional problems. Parents indicate the frequency of children's behaviors with a 3-point Likert scale, from "not at all" to "often". This produces, among other things, two scores for the presence of either internalizing or externalizing behaviors. Four subscales, namely "anxious/depressed", "emotionally reactive", "withdrawn" and "somatic complaints", determine the internalizing behavior score (clinical cutoff $>17$ ), whereas the "attention problems" and "aggressive behavior" subscales are integrated to provide the externalizing behavior score (clinical cutoff $>24$ ). These scores provide information about the sample's clinical profile at baseline. Cronbach's alpha for the different subscales is between .63 and .86 . For the present study, Cronbach's alpha was .88 .

\subsection{Procedure}

All children and their parents took part in pre-test and post-test sessions in a quiet room at school. Experimenters met the children twice per session to administer each measure. Parents were systematically met once at pre- and post-test and could receive help from the experimenter with completing the questionnaires if they wished. After pre-test, children were randomly allocated to the control or experimental group. Children in the experimental group attended the new "SIP program for children" described below, while children from the control group attended the same training after post-test.

\subsection{1 "SIP program for children" (Jacobs \& Nader-Grosbois, 2018)}

This new program is based on the SIP model (Crick \& Dodge, 1994) and on a review of studies in which effective SIP training is used with preschoolers at risk of developmental disorder or with a preschool developmental age. It consisted of eight 45-minute sessions. Children were allocated to subgroups of three. These training sessions took place twice a week in a quiet room at school. The sessions' complexity increased over time and observed strictly the order of processing social information. Using a range of materials, training activities dealt with hypothetical social situations. All types of situation used in this SIP program are described in Appendix B. There were situations related to provocation (24), social exclusion (22), conflict (16), transgression (12), frustration (5), ambiguous situations (4), cooperation situations (9) and prosocial (6) situations. Material elicited both appropriate and inappropriate situations although negative situations were more numerous because they have been found to be the most problematic for children with IDs (Matthys, Maassen, Cuperus, \& Van Engeland, 2001). Concretely, each session started with a brief reminder of the previous session. Then, one to three activities were carried out, using generally pictures, cards or game eliciting a positive or negative social situation (e.g. Cards Boxes - children have to choose in which box the card has to go, the "good box" or the "bad box" considering the social behavior illustrated). Each session ended by reading a pictorial book. During all the sessions, the experimenter used techniques adapted to the objectives of the training (see Appendix C). For example, the experimenter always asked the same questions in a specific order respecting SIP steps. It led to a cognitive reasoning routine that was consistent with the sequential model of processing of social information. It also helped children with IDs to focus on one relevant element by inhibiting distractors, and to generalize their knowledge. Experimenter encouraged child to call out these questions in order to support the use of self-verbalization or future 
self-instruction. It is all the more important given the positive link between verbal developmental age and social problem-solving skills (Jacobs et al., Submitted). In order to foster SIP application, experimenter always asked if the child experienced this kind of social situations and how he or she acted or could act. Material had therefore been chosen considering the probability that children had to experience these situations during interactions with peers or adults. During all sessions, experimenter looked out for respecting children's weaknesses and strengths in their profiles, as well as their zone of proximal development.

\section{Findings}

\subsection{Descriptive Statistics on Participants}

As can be seen in Table 1, after the pre-test session, the two groups did not differ.

Table 1. Demographic and individual characteristics: mean scores and standard deviations for each group in pre-test and between-group comparisons

\begin{tabular}{|c|c|c|c|c|}
\hline & & $\begin{array}{l}\text { Control group } \\
(n=15)\end{array}$ & $\begin{array}{l}\text { Experimental } \\
\text { group } \\
(n=15)\end{array}$ & \\
\hline \multicolumn{2}{|l|}{ Variables } & $M(\mathrm{SD})$ & $M(\mathrm{SD})$ & $X^{2 /} t$ \\
\hline \multicolumn{2}{|l|}{ Sex (\% boys) } & $66 \%$ & $47 \%$ & 1.22 \\
\hline \multicolumn{2}{|l|}{ CA (in months) } & $109.6(12.51)$ & $110.13(27.41)$ & -.07 \\
\hline \multicolumn{2}{|l|}{ GDA (in months) } & $63.47(16.18)$ & $62.89(12.13)$ & .11 \\
\hline \multirow[t]{3}{*}{ Family variables } & Family income & $3.20(1.15)$ & $2.92(.86)$ & .71 \\
\hline & Mothers' education $(\max =7)$ & $2.45(1.44)$ & $4.6(2.88)$ & -2.13 \\
\hline & Fathers' education $(\max =7)$ & $3.33(1.22)$ & $5(2.08)$ & -2.01 \\
\hline \multirow[t]{4}{*}{ SIP } & RES total & $61.47(20.18)$ & $64.07(15.9)$ & -.39 \\
\hline & RES judgment score & $25.07(2.71)$ & $25.13(2.75)$ & -.07 \\
\hline & RES identification score & $10.6(2.13)$ & $12.07(1.87)$ & -2 \\
\hline & RES justification score & $26.67(16.88)$ & $26.87(12.12)$ & -.04 \\
\hline \multirow[t]{2}{*}{ Emotion regulation } & Emotion regulation & $3.01(.33)$ & $2.84(.48)$ & 1.07 \\
\hline & Emotion dysregulation & $2.01(.35)$ & $2.12(.57)$ & -.57 \\
\hline \multirow[t]{5}{*}{ Social adjustment } & EASE total & $59.07(18.66)$ & $55.14(16.02)$ & .59 \\
\hline & EASE ToM & $28.93(9.8)$ & $25.71(7.78)$ & .96 \\
\hline & EASE social skills & $30.14(9.44)$ & $29.36(8.68)$ & .23 \\
\hline & SCBE - social competences & $106(23.48)$ & $107.17(29.19)$ & -.12 \\
\hline & SCBE - general adjustment & $244.36(40.49)$ & $247.06(54.65)$ & -.15 \\
\hline \multirow{4}{*}{$\begin{array}{l}\text { Social } \\
\text { maladjustment }\end{array}$} & CBCL externalizing behaviors & $16.47(10.44)$ & $17.36(11.06)$ & -.21 \\
\hline & CBCL internalizing behaviors & $17.53(9.03)$ & $19(8.76)$ & -.41 \\
\hline & SCBE externalizing problems & $65(13.58)$ & $71.49(20.11)$ & -1 \\
\hline & SCBE internalizing problems & $73.36(18.08)$ & $68.41(11.82)$ & .86 \\
\hline \multirow{8}{*}{$\begin{array}{l}\text { Dimensions } \\
\text { social skills and } \\
\text { behavior }\end{array}$} & Depressive-happy & $36(8.06)$ & $33.11(6.53)$ & 1.04 \\
\hline & Anxious-secure & $33.21(10.22)$ & $30.43(7.85)$ & .81 \\
\hline & Isolated-integrated & $35.21(10.11)$ & $32.68(6.02)$ & .81 \\
\hline & Dependent-autonomous & $29.78(9.41)$ & $27.98(9.23$ & .51 \\
\hline & Angry-tolerant & $24.57(5.97)$ & $28.07(11.81)$ & -.99 \\
\hline & Aggressive-controlled & 30.07 (4.43) & $32.28(8.49)$ & -.86 \\
\hline & Egoistic-prosocial & $22.93(5.89)$ & $30.29(10.47)$ & -2.29 \\
\hline & Resistant-cooperative & $32.57(6.76)$ & $32.23(10.35)$ & .10 \\
\hline
\end{tabular}

Note. $\overline{C A}=$ Chronological Age; GDA $=$ Global Developmental Age; $\mathrm{CBCL}=$ Child Behavior Checklist; EASE $=$ Social Adjustment Scale for Children; $\mathrm{SCBE}=$ Social Competences Behavior Evaluation scales . 
Table 2. Within-group comparison: means and standard deviations on pre-test, post-test in SIP, emotion regulation, social (mal)adjustment, socio-affective profiles, and their difference for each group and $t$-test score for the pre-test/post-test difference

\begin{tabular}{|c|c|c|c|c|c|c|c|c|c|}
\hline & & \multicolumn{3}{|c|}{ Control group } & \multicolumn{2}{|c|}{ Experimental group } & \multirow{2}{*}{\multicolumn{2}{|c|}{ Analysis }} & \multirow[b]{3}{*}{$\begin{array}{l}\text { Partial } \\
\text { Eta }^{2}\end{array}$} \\
\hline & & Pre-test & Post-test & & Pre-test & Post-test & & & \\
\hline Variables & & $\begin{array}{c}M \\
(\mathrm{SD})\end{array}$ & $\begin{array}{c}M \\
(\mathrm{SD})\end{array}$ & $t(14)$ & $\begin{array}{c}M \\
(\mathrm{SD})\end{array}$ & $\begin{array}{c}M \\
(\mathrm{SD})\end{array}$ & $t(14)$ & $\begin{array}{l}\text { Group by } \\
\text { time } \\
\text { interaction } \\
F(1)\end{array}$ & \\
\hline \multirow[t]{4}{*}{ SIP } & RES total & $\begin{array}{c}61.47 \\
(20.18)\end{array}$ & $\begin{array}{l}63.53 \\
(21.0)\end{array}$ & .03 & $\begin{array}{l}64.07 \\
(15.9)\end{array}$ & $\begin{array}{c}92.43 \\
(11.49)\end{array}$ & $6.78 * * * *$ & $7.89 * *$ & .23 \\
\hline & RES judgment & $\begin{array}{l}25.07 \\
(2.71)\end{array}$ & $\begin{array}{l}23.93 \\
(3.39)\end{array}$ & -.86 & $\begin{array}{l}25.13 \\
(2.75)\end{array}$ & $\begin{array}{c}27 \\
(1.88)\end{array}$ & $-.07 * * *$ & $4.55^{*}$ & .14 \\
\hline & RES identification & $\begin{array}{c}10.6 \\
(2.13)\end{array}$ & $\begin{array}{c}11.6 \\
(2.26)\end{array}$ & .77 & $\begin{array}{l}12.07 \\
(1.87)\end{array}$ & $\begin{array}{l}12.86 \\
(1.46)\end{array}$ & $2.28^{*}$ & .02 & \\
\hline & RES justification & $\begin{array}{c}26.67 \\
(16.88)\end{array}$ & $\begin{array}{c}28 \\
(16.0)\end{array}$ & -.02 & $\begin{array}{c}26.87 \\
(12.12)\end{array}$ & $\begin{array}{l}52.57 \\
(9.71)\end{array}$ & $6.93 * * * *$ & $10.54 * *$ & .28 \\
\hline \multirow[t]{3}{*}{$\begin{array}{l}\text { Social } \\
\text { (mal)adjustment }\end{array}$} & EASE total & $\begin{array}{c}60.91 \\
(17.01)\end{array}$ & $\begin{array}{c}61.73 \\
(18)\end{array}$ & .32 & $\begin{array}{l}51.33 \\
(21.4)\end{array}$ & $\begin{array}{c}72.17 \\
(14.34)\end{array}$ & $3.31 *$ & $12.38^{* *}$ & .45 \\
\hline & $\begin{array}{c}\text { Externalizing } \\
\text { problems }\end{array}$ & $\begin{array}{c}65.25 \\
(13.91)\end{array}$ & $\begin{array}{l}67.57 \\
(21.1)\end{array}$ & .27 & $\begin{array}{c}71.73 \\
(21.27)\end{array}$ & $\begin{array}{c}77.1 \\
(15.52)\end{array}$ & 1.3 & .09 & \\
\hline & $\begin{array}{l}\text { Internalizing } \\
\text { problems }\end{array}$ & $\begin{array}{c}73 \\
(19.12)\end{array}$ & $\begin{array}{l}70.22 \\
(15.1)\end{array}$ & -.36 & $\begin{array}{c}70.2 \\
(10.04)\end{array}$ & $\begin{array}{c}78.47 \\
(13.95)\end{array}$ & $3.17 *$ & 1.57 & \\
\hline \multirow{8}{*}{$\begin{array}{l}\text { Dimensions of } \\
\text { social skills and } \\
\text { behavior }\end{array}$} & Depressive-happy & $\begin{array}{c}36 \\
(8.06)\end{array}$ & $\begin{array}{l}34.84 \\
(8.11)\end{array}$ & -.56 & $\begin{array}{l}33.11 \\
(6.53)\end{array}$ & $\begin{array}{l}37.36 \\
(8.51)\end{array}$ & $2.16^{\mathrm{a}}$ & 1.88 & \\
\hline & Anxious-secure & $\begin{array}{c}33.21 \\
(10.22)\end{array}$ & $\begin{array}{l}32.95 \\
(8.21)\end{array}$ & -.33 & $\begin{array}{l}30.43 \\
(7.85)\end{array}$ & $\begin{array}{l}31.73 \\
(9.59)\end{array}$ & 1.17 & .84 & \\
\hline & Isolated-integrated & $\begin{array}{c}35.21 \\
(10.11)\end{array}$ & $\begin{array}{l}35.27 \\
(5.46)\end{array}$ & -.35 & $\begin{array}{l}32.68 \\
(6.02)\end{array}$ & $\begin{array}{l}34.91 \\
(9.13)\end{array}$ & $2.38^{*}$ & 1.95 & \\
\hline & Dependent-autonomous & $\begin{array}{l}29.78 \\
(9.41)\end{array}$ & $\begin{array}{l}27.63 \\
(9.72)\end{array}$ & -.54 & $\begin{array}{l}27.98 \\
(9.23\end{array}$ & $\begin{array}{l}33.79 \\
(8.92)\end{array}$ & $5.24 * * *$ & 3.78 & \\
\hline & Angry-tolerant & $\begin{array}{l}24.57 \\
(5.97)\end{array}$ & $\begin{array}{l}27.96 \\
(11.8)\end{array}$ & .43 & $\begin{array}{c}28.07 \\
(11.81)\end{array}$ & $\begin{array}{c}32.02 \\
(11.13)\end{array}$ & 1.25 & .21 & \\
\hline & Aggressive-controlled & $\begin{array}{l}30.07 \\
(4.43)\end{array}$ & $\begin{array}{l}31.96 \\
(8.55)\end{array}$ & .21 & $\begin{array}{l}32.28 \\
(8.49)\end{array}$ & $\begin{array}{l}32.36 \\
(9.87)\end{array}$ & 1.2 & .21 & \\
\hline & Egoistic-prosocial & $\begin{array}{l}22.93 \\
(5.89)\end{array}$ & $\begin{array}{l}28.56 \\
(10.6)\end{array}$ & 1.13 & $\begin{array}{c}30.29 \\
(10.47)\end{array}$ & $\begin{array}{c}30 \\
(10.46)\end{array}$ & .88 & .16 & \\
\hline & Resistant-cooperative & $\begin{array}{l}32.57 \\
(6.76)\end{array}$ & $\begin{array}{l}32.72 \\
(11.4)\end{array}$ & -.12 & $\begin{array}{c}32.23 \\
(10.35)\end{array}$ & $\begin{array}{l}37.18 \\
(8.93)\end{array}$ & $3.66 * *$ & 1.37 & \\
\hline \multirow[t]{2}{*}{ Emotion regulation } & ERC regulation & $\begin{array}{l}3.01 \\
(.37)\end{array}$ & $\begin{array}{l}3.12 \\
(.47)\end{array}$ & -.01 & $\begin{array}{l}2.84 \\
(.48)\end{array}$ & $\begin{array}{l}3.11 \\
(.62)\end{array}$ & $2.59 *$ & $3.97^{\mathrm{a}}$ & .15 \\
\hline & ERC dysregulation & $\begin{array}{l}2.09 \\
(.35)\end{array}$ & $\begin{array}{l}2.07 \\
(.64)\end{array}$ & .03 & $\begin{array}{l}2.12 \\
(.57)\end{array}$ & $\begin{array}{c}2.1 \\
(.78)\end{array}$ & -.08 & .01 & \\
\hline
\end{tabular}

Note. = post-test/pre-test difference; SIP = Social Information Processing; RES = Social problem-solving task; ERC = Emotion Regulation Checklist; EASE = Social Adjustment Scales for children; SCBE $=$ Social Competences Behavior Evaluation scales; ${ }^{*} \mathrm{p} \leq .05, * * \mathrm{p} \leq .01, * * * \mathrm{p} \leq .001,{ }^{*} * * * p=.000,{ }^{\mathrm{a}}=p=.059$.

A qualitative profile analysis revealed that in terms of social problem-solving competences, all these children had strong judgment and identification scores, but found it harder to justify their choices. The CBCL scores indicated that children in both groups displayed internalizing behaviors at a clinical level. By contrast, the externalizing and internalizing problems scores of SCBE yielded T-scores between 45 and 50. For the 8 subscales, T-scores were between 40 and 50 . These children had scores consistent with the average scores of a representative sample. 


\subsection{Results for Social Problem-Solving Abilities After Training}

Thanks to ANOVAs on repeated measures, the interaction effect of group by time indicated that participants in the experimental group had improved their abilities in social problem-solving at post-test $\left(F(1)=7.89 ; p=.009 ; \eta^{2}=.23\right)$. As can be seen in Table 2, children who had received the training displayed better abilities in social judgment $(F(1)=$ $\left.4.55 ; p=.042 ; \eta^{2}=.14\right)$ and in justifying social behavior $\left(F(1)=7.89 ; p=.009 ; \eta^{2}=.23\right)$. In terms of their justification scores, compared to the control group, children who had received the training produced more complex justifications related to social consciousness $\left(F(1)=15.67 ; p=.000 ; \eta^{2}=.37\right)$ and social rules $\left(F(1)=27.72 ; p=.000 ; \eta^{2}=.51\right)$. Similarly, interaction effects of group by time indicated that the control group produced more incoherent responses $(F(1)$ $\left.=8.01 ; p=.009 ; \eta^{2}=.23\right)$ and descriptive responses $\left(F(1)=11.14 ; p=.002 ; \eta^{2}=.29\right)$. Moreover, when children were presented with cards illustrating protagonist's bad social behavior, they were easily able to justify why the behavior was inappropriate $\left(F(1)=14.79 ; p=.001 ; \eta^{2}=.35\right)$.

\subsection{Results for Emotion Regulation and Social (Mal)Adjustment After Training}

As can be seen in Table 2, after the "SIP program for children", children were perceived by their parents at post-test as regulating their emotions better $(t(14)=2.59 ; p=.021 ; d=.50)$. However, no significant effect was obtained when the results in post-test of the experimental group are compared to its own pre-test and to the control group (i.e. no time per group interaction effect).

After training, parents evaluated children who had received the training as more socially adjusted. ANOVA on repeated measures indicated a group by time interaction effect for the EASE - total score $\left(F(1)=14.79 ; p=.001 ; \eta^{2}=.35\right)$. Moreover, children improved equally on both sub-scores, for ToM $\left(F(1)=11.81 ; p=.004 ; \eta^{2}=.43\right)$ and social skills $\left(F(1)=11.81 ; p=.004 ; \eta^{2}=.44\right)$.

The social profiles of children in the experimental group were evaluated by parents at post-test as more socially competent $(t(14)=-3.37 ; p=.008 ; d=.57)$ than in the pre-test. When the results in post-test of the experimental group are compared to its own pre-test and to the control group, no significant effect was obtained in global scores (i.e. no time per group interaction effect). However, looking at specific dimensions, after the training children in the experimental group seemed more integrated $(t(14)=-2.38 ; p \leq .05 ; d=.29)$, autonomous $(t(14)=-5.24 ; p=.001 ; d$ $=.64)$ and cooperative $(t(14)=-3.66 ; p=.005 ; d=.32)$. They were therefore perceived as displaying fewer internalizing problems than at pre-test $(t(14)=-3.17 ; p=.011 ; d=.68)$.

To investigate whether the training sessions had contributed to the children's social adjustment, a hierarchical multiple regression analysis was conducted. In Model 1, chronological and developmental ages were entered; in Model 2, the pre-test results of RES were entered; in Model 3, the pre-test results of EASE were entered; in Model 4, group condition was entered. Model 4 explained the post-test result for social adjustment (EASE) moderately well $\left(\beta=.48 ; \mathrm{R}_{\text {adj }}{ }=.57 ; p\right.$ $=.011)$. Pre-test result in $\operatorname{EASE}(\beta=.73 ; p=.003)$ and group condition $(\beta=.51 ; p=.012)$ were the only significant predictors of post-test result in EASE.

\section{Discussion}

The aim of this study was to test the effectiveness of a SIP training created specifically for elementary school children with IDs namely the "SIP program for children". The performance in social problem-solving, social adjustment and emotion regulation of children who had token part in the training were analyzed in comparison to a control group. Results revealed that children trained improved their SIP skills and are perceived as displaying better social-emotional competences.

As demonstrated by other studies (Anderson \& Kazantzis, 2008; Cote, 2011; Crites \& Dunn, 2004; Nestler \& Goldbeck, 2011; O'Reilly et al., 2004; Vlachou \& Stavroussi, 2016), children with IDs seemed receptive to SIP training and according to the present study, particularly to the "SIP program for children". Results demonstrated that our program enhanced problem-solving competences. More precisely, children who had participated in SIP training detected and justified more easily if and why a behavior was socially appropriate or not. The same results were obtained by Jacobs et al. (2016). Cote (2011) also indicated that after participating in social problem solving intervention, students with IDs were more able to identify correctly the social problems. Improvement in the judgement score reflected a correct identification of social and emotional cues (Step 1) and an appropriate interpretation by the children (Step 2). For instance, a child is able to determine the inadequacy of a social behavior of sharing if he or she identified cues indicating a protagonist's sadness and the other protagonist's intention not to share popcorn. This enhancement is an encouraging finding, because children with IDs display deficits in the first two steps of processing social information (van Nieuwenhuijzen et al., 2004; van Nieuwenhuijzen et al., 2009). After attending the "SIP program for children", children with IDs found it easier to understand why a particular behavior is socially appropriate or not. As Jacobs et al. (2016) observed, they used justification based on social consciousness and rules. In the example cited above, the 
children could explain that the other's behavior was inappropriate by saying: "That behavior is mean, and the other girl will be sad" or "This behavior is not nice; we must share with someone who has nothing". To explain it properly, children had to understand the goal (Step 3) and the protagonist's intention in critical social situation. This improvement reflected therefore a better understanding of goal situation and could enhance after the response generation and selection (Steps 4 and 5). Children who had participated in training also displayed better justification competences, particularly for cards depicting negative situations. Yet, it is known that children with IDs found it harder to cope with negative social situations (Hippolyte et al., 2010; van Nieuwenhuijzen et al., 2004; van Nieuwenhuijzen et al., 2009). This specific effect is a very promising outcome.

Concerning the causal contribution of SIP to social adjustment, the children were perceived as more socially adjusted by their parents after SIP training. Similarly, in the study of Nestler and Goldbeck (2011), after SIP training, children and adolescents were seen as more socially competent. Regarding their socio-affective profiles after training, the parents perceived the children in experimental group, as less isolated, less dependent, and slightly happier. This last result was also observed by Anderson and Kazantzis (2008). In other words, parents described their children as more respectful of social rules and more socially competent. More precisely, children are perceived as more integrated in their interactions with peers and more cooperative and autonomous in their interactions with adults. Additionally, $57 \%$ of the children's social adjustment score at post-test was explained by their characteristics and their skills at pre-test, particularly their social adjustment abilities at pre-test, and by their group condition, namely their attendance of the program. This outcome firstly underlined that it is crucial to explore these children's profiles given the effect of their present skills on their future abilities. Professionals had to analyze both strengths and weaknesses in these children. Secondly, it highlighted the effectiveness of a program focusing specifically on SIP. The participation in such training could act as a protective factor. Concerning the socio-affective profile, children of the experimental group tended to display fewer internalizing problems after the training. This result is more encouraging than the one obtained by Nestler and Goldbeck (2011), who found no effect. Since little is known about internalizing problems in children with developmental disabilities (Hauser-Cram \& Woodman, 2016), this result is crucial given that such behaviors could emphasize social withdrawal and impede social inclusion. Regarding emotion regulation, after attending the "SIP program for children", the children seemed to respond positively to their parents and peers, to be emphatic and to express their emotions appropriately. However, no effect was observed on their ability to control their impulsivity, angriness or frustration. This could be explained by the profile of children with IDs, who have greater difficulties in handling situations where such emotions are aroused (Baurain \& Nader-Grosbois, 2013).

When interpreting the results of this study, certain strengths and limitations have to be considered. Given the quite small sample size, the statistical power of our findings is limited. Moreover, some children missed one $(n=5)$ or two sessions $(n=2)$. After an absence, children participated in a 10-minute feedback session given by trainers and other children. This focused on what had been done during the missed session. About the sample, despite the fact that all the children were recruited in special elementary schools, children had between 6 and 12 years. It could be seen as a large range. Nevertheless, Jacobs et al. (Submitted) have revealed the specific importance of developmental age in SIP profile of children with IDs. Yet, as it was an inclusion criteria, the developmental age of the sample was between 3 and a half and 7 years. The creation of a control group allowed to assess the effects of time and of group participation while only a few studies included it (Jacobs et al., 2016; Nestler \& Goldbeck, 2011). Concerning measures, additional assessments notably on language (Hippolyte et al., 2010; Lohmann \& Tomasello, 2003; Westby \& Robinson, 2014), executive functions (such as working memory; Dennis, Agostino, Roncadin, \& Levin, 2009; such as working memory; Lecce \& Bianco, 2018; or inhibition; Perner, Lang, \& Kloo, 2002), or hostile attribution (as in Houssa, Nader-Grosbois \& Volckaert, 2018) might have been useful. Another SIP measure, such as the "social processing measure" created by van Nieuwenhuijzen and colleagues (2011), could pinpoint effects on specific SIP steps. Another limitation is that the children did not take part in a follow-up session. Effects described were middle-term effects of the "SIP program for children". About the program design, this research underlined the importance of focusing a specific target to foster social problem-solving, namely SIP steps. It also emphasized that the use of clear and repetitive instructions (Cote, 2011; Shure, 1993) and schedules ensured the effectiveness of intervention. It allowed children to improve their performance in new critical social situations. Crites and Dunn (2004), O'Reilly and colleagues (2004), and Nestler and Goldbeck (2011) demonstrated that, after a social problem-solving program, adolescents and adults with IDs dealt with new social situations easily. Similarly, opportunities of self-verbalization (Nestler \& Goldbeck, 2011) and discussions on social situation experienced by children themselves (Crites \& Dunn, 2004) would ensure generalization of learned competences. Dodge (2014) underlined that SIP process is generally used unconsciously except in complex situations requiring a conscient detection of cues or generation of very new response. The awareness of this process would therefore help children which faced difficulties in social problem-solving. According to Dodge (2014), in order to foster SIP abilities, it is important that children overlearned a routine, notably by using strategies as self-verbalization of key questions or metacognition. 
To put the findings in perspective, it would be interesting to investigate the effects of "SIP program for children" on variables related to Theory of Mind. Jacobs and colleagues (2016) have already explored this link, but only with a one-shot training session. Future studies also need to explore the effects of SIP intervention on other variables such as executive functions. Cognitive and executive functions (inhibition, planning, attention control, working memory etc.) are some of the underlying processes of SIP. Difficulties in inhibition are linked with hostile attribution bias, while working memory is related with the encoding of cues in children with mild to borderline IDs (van Nieuwenhuijzen \& Vriens, 2012). Recently, Van Rest and colleagues (2018) observed that SIP mediates the link between executive functions and aggressive behaviors. Future research could therefore test the effect of SIP training on a larger group, but also in comparison with an intervention on executive functions, such as that implemented by Houssa and colleagues (2017) with preschoolers with externalizing behavior.

According to the present findings, the SIP child program seemed effective and fostering social problem-solving, social adjustment and emotion regulation. It supports the evidence of a potential causal contribution of SIP on socio-emotional competences. This means that it would be possible to help children with IDs, by giving them specific clinical support, to improve their ability to deal with social situations, especially critical ones. This approach would support autonomy and ensure social inclusion.

\section{Recommendations}

Given these promising results, it would be helpful to train professionals and teachers so they can implement this SIP training. Moreover, parents could foster social adjustment and emotion regulation and therefore promote the social inclusion of their child, by using adapted materials and techniques inspired by this SIP training. During our interviews with parents, they were looking for practical activities to do with their child to ensure the learning that they notified. In fact, both teachers and parents reported the use of key questions of children in their daily interactions. This strategy seemed to help them to solve adequately critical social situations (conflict, frustrating situations, difficulty to respect social rules...). Finally, the evaluation feedback to teachers and parents is as important as the training is, as long as it highlights the child's weaknesses and strengths. In fact, we had the opportunity to see that they generally underestimated child's competences. When we pointed their abilities via performances assessments and when they observed improvements, they encourage their child to have more social interactions and to solve social situations adequately.

\section{References}

Achenbach, T. M. (1991). Manual for the child behavior checklist/4-18 and 1991 Profile.

Anderson, G., \& Kazantzis, N. (2008). Social problem-solving skills training for adults with mild intellectual disability: A multiple case study. Behaviour Change, 25(2), 97-108. https://doi.org/10.1375/bech.25.2.97

Baker, B. L., McIntyre, L. L., Blacher, J., Crnic, K. A., Edelbrock, C., \& Low, C. (2003). Pre-school children with and without developmental delay: Behaviour problems and parenting stress over time. Journal of Intellectual Disability Research, 47(4-5), 217-230. https://doi.org/10.1046/j.1365-2788.2003.00484.x

Barisnikov, K., Van der Linden, M., \& Hippolyte, L. (2004). Tâche de résolution sociale. Genève.

Baurain, C., \& Nader-Grosbois, N. (2012). Socio-emotional regulation in children with intellectual disability and typically developing children in interactive contexts. ALTER-European Journal of Disability Research, 6(2), 75-93. https://doi.org/10.1016/j.alter.2012.02.001

Baurain, C., \& Nader-Grosbois, N. (2013). Theory of Mind, Socio-Emotional Problem-Solving, Socio-Emotional Regulation in Children with Intellectual Disability and in Typically Developing Children. Journal of Autism and Developmental Disorders, 43(5), 1080-1097. https://doi.org/10.1007/s10803-012-1651-4

Bernard-Opitz, V., Sriram, N., \& Nakhoda-Sapuan, S. (2001). Enhancing social problem solving in children with autism and normal children through computer-assisted instruction. Journal of Autism and Developmental Disorders, 31(4), 377-384. https://doi.org/10.1023/A:1010660502130

Cote, D. L. (2011). Implementing a problem-solving intervention with students with mild to moderate disabilities. Intervention in School and Clinic, 46(5), 259-265. https://doi.org/10.1177/1053451210395387

Crick, N. R., \& Dodge, K. A. (1994). A review and reformulation of social information-processing mechanisms in children's social adjustment. Psychological bulletin, 115(1), 74-101. https://doi.org/10.1037/0033-2909.115.1.74

Crites, S. A., \& Dunn, C. (2004). Teaching social problem solving to individuals with mental retardation. Education and Training in Developmental Disabilities, 301-309. 
Crnic, K. A., Hoffman, C., Gaze, C., \& Edelbrock, C. (2004). Understanding the emergence of behavior problems in young children with developmental delays. Infants \& Young Children, 17(3), 223-235. https://doi.org/10.1097/00001163-200407000-00004

Dekker, M. C., \& Koot, H. M. (2003). DSM-IV disorders in children with borderline to moderate intellectual disability. I: Prevalence and impact. Journal of the American Academy of Child \& Adolescent Psychiatry, 42(8), 915-922. https://doi.org/10.1097/01.CHI.0000046892.27264.1A

Dekker, M. C., Koot, H. M., Ende, J. V. D., \& Verhulst, F. C. (2002). Emotional and behavioral problems in children and adolescents with and without intellectual disability. Journal of Child Psychology and Psychiatry, 43(8), 1087-1098. https://doi.org/10.1111/1469-7610.00235

Dennis, M., Agostino, A., Roncadin, C., \& Levin, H. (2009). Theory of mind depends on domain-general executive functions of working memory and cognitive inhibition in children with traumatic brain injury. Journal of Clinical Experimental Neuropsychology, 31(7), 835-847. https://doi.org/10.1080/13803390802572419

Dodge, K. A. (2014). A social information processing model of social competence in children. In M. Pelmutter (Ed.), Cognitive perspectives on children's social and behavioral development (pp. 77-126). New York: Psychology Press.

Emerson, E. (2003). Prevalence of psychiatric disorders in children and adolescents with and without intellectual disability. Journal of Intellectual Disability Research, 47(1), 51-58. https://doi.org/10.1046/j.1365-2788.2003.00464.x

Gascon, H., Bibeau, M.-J., Grondin, J., \& Milot, É. (2010). Chapitre 3. Bien-être psychologique des élèves adolescents présentant un retard mental léger. In Haelewyck M.-C. \& Gascon H. (Eds.), Adolescence et retard mental (pp. 49-59). Bruxelles, Belgique: De Boeck Supérieur. https://doi.org/10.3917/dbu.haele.2010.01.0049

Hauser-Cram, P., \& Woodman, A. C. (2016). Trajectories of internalizing and externalizing behavior problems in children with developmental disabilities. Journal of abnormal child psychology, 44(4), 811-821. https://doi.org/10.1007/s10802-015-0055-2

Hippolyte, L., Iglesias, K., Van der Linden, M., \& Barisnikov, K. (2010). Social reasoning skills in adults with Down syndrome: the role of language, executive functions and socio-emotional behaviour. Journal of Intellectual Disability Research, 54(8), 714-726. https://doi.org/10.1111/j.1365-2788.2010.01299.x

Houssa, M. (2016). Troubles externalisés du comportement et cognition sociale: impact d'un entrainement en cognition sociale sur les troubles externalisés du comportement et l'(in) adaptation sociale chez le jeune enfant. UCL-Université Catholique de Louvain,

Houssa, M., Jacobs, E., \& Nader-Grosbois, N. (2016). Impact of short-term training in social cognition in preschoolers with externalizing behavior. Journal of Education and Training Studies, 5(1), 110-123. https://doi.org/10.11114/jets.v5i1.2081

Houssa, M., Volckaert, A., Nader-Grosbois, N., \& Noël, M.-P. (2017). Differential Impact of an Executive-Function and a Social Cognition Training on Preschoolers with Externalizing Behavior Problems. Journal of Behavioral and Brain Science, 7(12), 598-620. https://doi.org/10.4236/jbbs.2017.712042

Hughes, C., Soares-Boucaud, I., Hochmann, J., \& Frith, U. (1997). Social behaviour in pervasive developmental disorders: Effects of informant, group and "theory-of-mind". European Child \& Adolescent Psychiatry, 6(4), 191-198. https://doi.org/10.1007/BF00539925

Jacobs, E., \& Nader-Grosbois, N. (2018). SIP Program for Children. UCLouvain. Louvain-La-Neuve.

Jacobs, E., Léonard, C., Nader-Grosbois, N., Houssa, M., \& Mazzone, S. (2016). Entrainer la cognition sociale auprès d'enfants présentant une déficience intellectuelle. Revue Francophone de la Déficience Intellectuelle, 27, 127-140. https://doi.org/10.7202/1043129ar

Jacobs, E., Simon, P., \& Nader-Grosbois, N. (Submitted). Social cognition in children with non-specific intellectual disability: An exploratory study. Frontiers in psychology.

Jahoda, A., Pert, C., \& Trower, P. (2006). Frequent aggression and attribution of hostile intent in people with mild to moderate intellectual disabilities: An empirical investigation. American Journal on Mental Retardation, 111(2), 90-99. https://doi.org/10.1352/0895-8017(2006)111[90:FAAAOH]2.0.CO;2

Kasari, C., \& Bauminger, N. (1998). Social and emotional development in children with mental retardation. Handbook of Mental Retardation and Development, 411-433. 
Keogh, B. K., Bernheimer, L. P., Daley, S., \& Haney, M. (1989). Behaviour and adjustment problems of young developmentally delayed children. European Journal of Special Needs Education, 4(2), 79-90. https://doi.org/10.1080/0885625890040201

LaFrenière, P. J., Dumas, J. E., Capuano, F., \& Dubeau, D. (1992). Development and validation of the Preschool Socioaffective Profile. Psychological Assessment, 4, 442-450. https://doi.org/10.1037/1040-3590.4.4.442

Lecce, S., \& Bianco, F. (2018). Working memory predicts changes in children's theory of mind during middle childhood: A training study. Cognitive Development, 47, 71-81. https://doi.org/10.1016/j.cogdev.2018.04.002

Leffert, J. S., \& Siperstein, G. N. (1996). Assessment of social-cognitive processes in children with mental retardation. American Journal on Mental Retardation.

Leffert, J. S., Siperstein, G. N., \& Millikan, E. (2000). Understanding social adaptation in children with mental retardation: A social-cognitive perspective. Exceptional Children, 66(4), 530-545. https://doi.org/10.1177/001440290006600406

Lohmann, H., \& Tomasello, M. (2003). The role of language in the development of false belief understanding: A training study. Child Development, 74(4), 1130-1144. https://doi.org/10.1111/1467-8624.00597

Matthys, W., Maassen, G., Cuperus, J., \& Van Engeland, H. (2001). The assessment of the situational specificity of children's problem behaviour in peer-peer context. The Journal of Child Psychology and Psychiatry and Allied Disciplines, 42(3), 413-420. https://doi.org/10.1111/1469-7610.00734

Merrell, K. W., \& Holland, M. L. (1997). Social-emotional behavior of preschool-age children with and without developmental delays. Research in Developmental Disabilities, 18(6), 393-405. https://doi.org/10.1016/S0891-4222(97)00018-8

Nader-Grosbois, N., \& Mazzone, S. (2015). Validation de la version francophone de l'Emotion Regulation Checklist (ERC-vf). Revue Européenne de Psychologie Appliquée, 65(1), 29-41. https://doi.org/10.1016/j.erap.2014.10.002

Nader-Grosbois, N., Houssa, M., \& Mazzone, S. (2013). How could Theory of Mind contribute the differentiation social adjustment profiles of children with externalizing behavior disorders and children with intellectual disabilities? Research in Developmental Disabilities, 34(9), 2642-2660. https://doi.org/10.1016/j.ridd.2013.05.010

Nader-Grosbois, N., Houssa, M., Jacobs, E., \& Mazzone, S. (2016). Comment soutenir efficacement les compétences émotionnelles et sociales d'enfants à besoins spécifiques en milieu préscolaire et scolaire? Bulletin de Psychologie, (4), 295-315. https://doi.org/10.3917/bupsy.544.0295

Nestler, J., \& Goldbeck, L. (2011). A pilot study of social competence group training for adolescents with borderline intellectual functioning and emotional and behavioural problems (SCT-ABI). Journal of Intellectual Disability Research, 55(2), 231-241. https://doi.org/10.1111/j.1365-2788.2010.01369.x

O’Reilly, M. F., Lancioni, G. E., Sigafoos, J., O’Donoghue, D., Lacey, C., \& Edrisinha, C. (2004). Teaching social skills to adults with intellectual disabilities: a comparison of external control and problem-solving interventions. Research in Developmental Disabilities, 25(5), 399-412. https://doi.org/10.1016/j.ridd.2003.07.003

Perner, J., Lang, B., \& Kloo, D. (2002). Theory of mind and self-control: More than a common problem of inhibition. Child Development, 73(3), 752-767. https://doi.org/10.1111/1467-8624.00436

Radley, K. C., Ford, W. B., Battaglia, A. A., \& McHugh, M. B. (2014). The effects of a social skills training package on social engagement of children with autism spectrum disorders in a generalized recess setting. Focus on autism and other Developmental Disabilities, 29(4), 216-229. https://doi.org/10.1016/j.rasd.2006.08.006

Rubin, K. H., \& Krasnor, L. R. (1986). Social-cognitive and social behavioral perspectives on problem solving. Paper presented at the Cognitive perspectives on children's social and behavioral development. The Minnesota Symposia on Child Psychology.

Schultz, D., Ambike, A., Logie, S. K., Bohner, K. E., Stapleton, L. M., VanderWalde, H., Betkowski, J. A. (2010). Assessment of social information processing in early childhood: Development and initial validation of the Schultz test of emotion processing-Preliminary version. Journal of Abnormal child Psychology, 38(5), 601-613. https://doi.org/10.1007/s10802-010-9390-5

Shields, A., \& Cicchetti, D. (1997). Emotion regulation among school-age children: The development and validation of a new criterion Q-sort scale. Developmental Psychology, 33(6), 906-916. https://doi.org/10.1037/0012-1649.33.6.906 
Shure, M. B. (1993). I can problem solve (ICPS): Interpersonal cognitive problem solving for young children. Early Child Development and Care, 96(1), 49-64. https://doi.org/10.1080/0300443930960106

Taylor, J. (2002). A review of the assessment and treatment of anger and aggression in offenders with intellectual disability. Journal of Intellectual Disability Research, 46, 57-73. https://doi.org/10.1046/j.1365-2788.2002.00005.x

Thirion-Marissiaux, A. F., \& Nader-Grosbois, N. (2008). Theory of mind and socio-affective abilities in disabled children and adolescents. European Journal of Disability Research, 2(2), 133-155. https://doi.org/10.1016/j.alter.2008.02.003

van Nieuwenhuijzen, M., \& Vriens, A. (2012). (Social) Cognitive skills and social information processing in children with mild to borderline intellectual disabilities. Research in Developmental Disabilities, 33(2), 426-434. https://doi.org/10.1016/j.ridd.2011.09.025

van Nieuwenhuijzen, M., Orobio De Castro, B., Van der Valk, I., Wijnroks, L., Vermeer, A., \& Matthys, W. (2006). Do social information-processing models explain aggressive behaviour by children with mild intellectual disabilities in residential care? Journal of Intellectual Disability Research, 50(11), 801-812. https://doi.org/10.1111/j.1365-2788.2005.00773.x

van Nieuwenhuijzen, M., Orobio de Castro, B., Wijnroks, L., Vermeer, A., \& Matthys, W. (2004). The relations between intellectual disabilities, social information processing, and behaviour problems. European Journal of Developmental Psychology, 1(3), 215-229. https://doi.org/10.1080/17405620444000111

van Nieuwenhuijzen, M., Orobio de Castro, B., Wijnroks, L., Vermeer, A., \& Matthys, W. (2009). Social problem-solving and mild intellectual disabilities: Relations with externalizing behavior and therapeutic context. American Journal on Intellectual and Developmental Disabilities, 114(1), 42-51. https://doi.org/10.1352/2009.114:42-51

van Nieuwenhuijzen, M., Vriens, A., Scheepmaker, M., Smit, M., \& Porton, E. (2011). The development of a diagnostic instrument to measure social information processing in children with mild to borderline intellectual disabilities. Research in Developmental Disabilities, 32(1), 358-370. https://doi.org/10.1016/j.ridd.2010.10.012

Van Rest, M. M., Matthys, W., Van Nieuwenhuijzen, M., De Moor, M. H., Vriens, A., \& Schuengel, C. (2018). Social information processing skills link executive functions to aggression in adolescents with mild to borderline intellectual disability. Child neuropsychology, 1-26. https://doi.org/10.1080/09297049.2018.1495186

Vlachou, A., \& Stavroussi, P. (2016). Promoting social inclusion: a structured intervention for enhancing interpersonal problem-solving skills in children with mild intellectual disabilities. Support for Learning, 31(1), 27-45. https://doi.org/10.1111/1467-9604.12112

Webster-Stratton, C., \& Hammond, M. (1997). Treating children with early-onset conduct problems: A comparison of child and parent training interventions. Journal of Consulting and Clinical Psychology, 65(1), 93-109. https://doi.org/10.1037/0022-006X.65.1.93

Wechsler, D. (2004). Echelle d'intelligence de Wechsler pour la période préscolaire et primaire (Vol. 3). Paris Les éditions du Centre de Psychologie appliquée.

Westby, C., \& Robinson, L. (2014). A developmental perspective for promoting theory of mind. Topics in Language Disorders, 34(4), 362-382. https://doi.org/10.1097/TLD.0000000000000035

Zion, E., \& Jenvey, V. (2006). Temperament and social behaviour at home and school among typically developing children and children with an intellectually disability. Journal of Intellectual Disability Research, 50(6), 445-456. https://doi.org/10.1111/j.1365-2788.2006.00790.x

Ziv, Y., \& Sorongon, A. (2011). Social information processing in preschool children: Relations to sociodemographic risk and problem behavior. Journal of Experimental Child Psychology, 109(4), 412-429. https://doi.org/10.1016/j.jecp.2011.02.009 
Appendix A: SIP training studies involving individuals with mild to moderate intellectual disabilities

\begin{tabular}{|c|c|c|c|c|c|c|}
\hline \multicolumn{2}{|c|}{ References } & $\begin{array}{lll}\text { Crites } & \& & \text { Dunn } \\
(\mathbf{2 0 0 4 )} & & \\
\end{array}$ & $\begin{array}{l}\begin{array}{l}\text { O'Reilly et al. } \\
(2004)\end{array} \\
\end{array}$ & $\begin{array}{l}\text { Anderson \& } \\
\text { Kazantzis (2008) } \\
\end{array}$ & $\begin{array}{l}\text { Nestler \& Goldbeck } \\
(2011)\end{array}$ & Jacobs et al. (2016) \\
\hline \multirow[t]{2}{*}{ Sample } & Description & $\begin{array}{l}\text { Adolescents } \\
\text { CA: } M=17 \text { years } \\
\text { IQ: } M=51\end{array}$ & $\begin{array}{l}\text { Adults } \\
\text { CA: } M=33 \text { years } \\
(30 \text { to } 37)\end{array}$ & $\begin{array}{l}\text { Adults } \\
\text { CA: 19, 39, } 52 \\
\text { years }\end{array}$ & $\begin{array}{l}\text { Adolescents } \\
\text { CA: } M=17 \text { years } \\
\text { Total } n=77\end{array}$ & $\begin{array}{l}\text { Children } \\
\text { CA: } M=9,5 \text { years }(6 \\
\text { to } 12) \\
\text { GDA: } 4,5 \text { years } \\
\text { Total } n=12\end{array}$ \\
\hline & $\begin{array}{l}\text { Experimental/Control } \\
\text { groups (number) }\end{array}$ & $\begin{array}{c}\text { Expe.: } n=18 \\
\text { No control }\end{array}$ & $\begin{array}{l}\text { Expe.: } n=5 \\
\text { No control }\end{array}$ & $\begin{array}{l}\text { Expe.: } n=3 \\
\text { No control }\end{array}$ & $\begin{array}{c}\text { Expe.: } n=40 \\
\text { Control: } n=37\end{array}$ & $\begin{array}{c}\text { Expe..: } n=6 \\
\text { Control: } n=6\end{array}$ \\
\hline \multirow[t]{3}{*}{ Training } & Target & $\begin{array}{l}\text { Social problem- } \\
\text { solving }\end{array}$ & Social competences & $\begin{array}{l}\text { Social } \\
\text { problem-solving } \\
\text { Depressive } \\
\text { symptoms } \\
\end{array}$ & $\begin{array}{l}\text { Social problem-solving } \\
\text { Social competences } \\
\text { Aggressive behaviors }\end{array}$ & $\begin{array}{l}\text { Social } \\
\text { problem-solving }\end{array}$ \\
\hline & Timing sessions & $\begin{array}{l}10 \text { sessions } \\
1 \mathrm{~h} / \text { day } \\
\text { During } 10 \text { days }\end{array}$ & $\begin{array}{l}4-5 \text { sessions (60 } \\
\text { min.) } \\
1 \text { to } 2 \times \text { / week } \\
1 \text { month follow up }\end{array}$ & $\begin{array}{l}15 \text { sessions } \\
1 \text { month follow up }\end{array}$ & $\begin{array}{l}8 \text { sessions }(2 \mathrm{~h})+ \\
\text { feedback session }(4 \mathrm{~h}) \\
\text { During } 3 \text { months } \\
6 \text { months follow up }\end{array}$ & 1 session (45min.) \\
\hline & Individual/group & Group - classroom & Individual & Individual & Group & Group of 3 children \\
\hline \multirow[t]{2}{*}{$\begin{array}{l}\text { Variables/ } \\
\text { Measures in } \\
\text { pre- and } \\
\text { post-tests }\end{array}$} & $\begin{array}{lll}\text { SIP } \quad \text { or } & \text { social } \\
\text { problem-solving } & \end{array}$ & $\begin{array}{l}2 \text { performance-based } \\
\text { tasks: } \\
-\quad \text { Interpersonal } \\
\text { Cognitive } \\
\text { Problem-Solving } \\
\text { - Solve The Problem } \\
\text { Structured interview } \\
\text { - Curriculum } \\
\text { Knowledge Test } \\
\text { - Brainstorming } \\
\end{array}$ & $\begin{array}{l}\text { Observational } \\
\text { measure: Analysis } \\
\text { of problem-solving } \\
\text { competences }\end{array}$ & $\begin{array}{l}\text { Structured } \\
\text { interview } \\
\text { Social } \\
\text { Problem-Solving } \\
\text { Skills Measure }\end{array}$ & $\begin{array}{l}\text { Performance-based } \\
\text { task: - Hamet2- Social } \\
\text { problem-solving } \\
\text { - self-reported } \\
\text { questionnaire: Social } \\
\text { knowledge } \\
\text { questionnaire }\end{array}$ & $\begin{array}{l}\text { Performance-based } \\
\text { task: Social } \\
\text { problem-solving task } \\
\text { (RES) }\end{array}$ \\
\hline & $\begin{array}{l}\text { Related to other } \\
\text { variables }\end{array}$ & & & $\begin{array}{l}3 \quad \text { self-reported } \\
\text { questionnaires: } \\
\text { - Adaptive behavior } \\
\text { Scale Residential } \\
\text { - Adapted Zung } \\
\text { Anxiety and } \\
\text { Depression } \\
\text { Inventory } \\
\text { - Adapted } \\
\text { Rosenberg } \\
\text { Self-Esteem scale }\end{array}$ & $\begin{array}{l}\text { Observation via } \\
\text { video-recorded: } \\
\text { Role play behavior } \\
3 \quad \text { self-reported } \\
\text { questionnaires: } \\
\text { - Goal attainment scale } \\
\text { of The List of } \\
\text { Individual Symptoms } \\
\text { for Therapy Evaluation } \\
\text { - Social anxiety } \\
\text { U-questionnaire } \\
\text { - Teenage Inventory of } \\
\text { Social Skills }\end{array}$ & $\begin{array}{l}3 \text { performance-based } \\
\text { tasks: } \\
\text { - ToM-Emotions } \\
- \text { ToM-Beliefs } \\
-\quad \text { ToM Tasks } \\
\text { Battery-vf } \\
3 \quad \text { hetero-reported } \\
\text { questionnaires: } \\
\text {-Social Adjustment } \\
\text { scales for children } \\
\text {-Social competences } \\
\text { and Behavior } \\
\text { Evaluation scale } \\
\text {-Emotion Regulation } \\
\text { Checklist-vf }(\end{array}$ \\
\hline Material & $\begin{array}{l}\text { Eliciting critical social } \\
\text { situation }\end{array}$ & - Videos & Pictures & $\begin{array}{l}\text { Pictures } \\
\text { - Homework } \\
\text { - Relaxation }\end{array}$ & $\begin{array}{l}\text { Manual: Social } \\
\text { competences Training } \\
\text { for Adolescents with } \\
\text { Borderline Intelligence } \\
\text { - Movies } \\
\text { - Homework } \\
\text { - Self verbalization }\end{array}$ & $\begin{array}{l}\text { Manual of Brief SIP } \\
\text { program } \\
\text { - Pictures } \\
\text { - Games } \\
\text { - Videos } \\
\text { - Books }\end{array}$ \\
\hline \multirow[t]{4}{*}{ Techniques } & Repetition & $\mathbf{X}$ & & & $\mathbf{X}$ & \\
\hline & $\begin{array}{ll}\text { Corrective feedback/ } \\
\text { Explanation }\end{array}$ & & $\mathbf{X}$ & $\mathbf{X}$ & $\mathbf{X}$ & $\mathbf{X}$ \\
\hline & Asking for justification & & & $\mathbf{X}$ & & $\mathbf{X}$ \\
\hline & $\begin{array}{l}\text { Link with child's } \\
\text { experience }\end{array}$ & $\mathbf{X}$ & & $\mathbf{X}$ & $\mathbf{X}$ & $\mathbf{X}$ \\
\hline \multirow[t]{2}{*}{ Results } & $\begin{array}{l}\text { Effects on SIP, social } \\
\text { problem solving }\end{array}$ & $\mathbf{X}$ & $\mathbf{X}$ & $\mathbf{X}$ & $\mathbf{X}$ & $\mathbf{X}$ \\
\hline & $\begin{array}{l}\text { Effects on other } \\
\text { variables }\end{array}$ & & & $\begin{array}{c}\mathbf{X} \\
\text { Depression and } \\
\text { Behavior } \\
\end{array}$ & & $\begin{array}{c}\mathbf{X} \\
\text { Theory of Mind }\end{array}$ \\
\hline
\end{tabular}

Note: IDs = Intellectual disabilities; CA = Chronological Age; GDA = Global Developmental Age; IQ = Intellectual Quotient; $M=$ mean; $n=$ number of participants; $\mathrm{h}=$ hour; min. = minutes; Expe. $=$ Experimental. 
Appendix B: Material and eliciting social situations of "SIP program for children"

\begin{tabular}{|c|c|c|c|}
\hline & Material & $\begin{array}{l}\text { Eliciting critical social situations } \\
\text { (number of situations) }\end{array}$ & Descriptions \\
\hline \multirow{6}{*}{$\begin{array}{l}\text { A. Is this situation good } \\
\text { or bad? } \\
\text { SIP Steps 1, } 2\end{array}$} & \multirow[t]{5}{*}{ Pictures } & Provocation $(3)$ & $\begin{array}{l}\text { Boy does not want to share his } \\
\text { ball. }\end{array}$ \\
\hline & & Conflict (4) & $\begin{array}{l}\text { Mother is upset by the } \\
\text { inappropriate behavior of her } \\
\text { daughter. }\end{array}$ \\
\hline & & Social Exclusion (6) & $\begin{array}{l}\text { Other children exclude girl } \\
\text { because she smells bad. }\end{array}$ \\
\hline & & Prosocial (6) & $\begin{array}{l}\text { Mom helps her daughter who is } \\
\text { hurt while cycling. }\end{array}$ \\
\hline & & Transgression (2) & Girl steals a cookie. \\
\hline & Pictorial Book & Provocation & $\begin{array}{l}\text { Two bunnies argue because of } \\
\text { unintentional actions. }\end{array}$ \\
\hline \multirow[t]{8}{*}{$\begin{array}{l}\text { B. How to judge if it is } \\
\text { good or bad? } \\
\text { SIP Steps } 1,2\end{array}$} & \multirow[t]{3}{*}{$\begin{array}{l}\text { Stories (based on SIPI-P, } \\
\text { Ziv \& Sorongon, 2011) }\end{array}$} & Provocation & $\begin{array}{l}\text { A child comes and takes the } \\
\text { remote while Mikael is } \\
\text { watching TV. }\end{array}$ \\
\hline & & Social Exclusion & $\begin{array}{l}\text { Other children do not want to } \\
\text { let Mikael play with them. }\end{array}$ \\
\hline & & Ambiguous Situation & $\begin{array}{l}\text { A child spills his glass } \\
\text { accidentally on Mikael's lunch. }\end{array}$ \\
\hline & \multirow[t]{4}{*}{ Cards Boxes } & Provocation & $\begin{array}{l}\text { A boy throws sand in another } \\
\text { boy's face. }\end{array}$ \\
\hline & & Conflict & Two boys fight. \\
\hline & & Cooperation & $\begin{array}{l}\text { A daughter jumps into her } \\
\text { father's arms. }\end{array}$ \\
\hline & & Prosocial & $\begin{array}{l}\text { A girl plays a game that she has } \\
\text { just been given. }\end{array}$ \\
\hline & $\begin{array}{l}\text { Picture Book ("It is not } \\
\text { polite") }\end{array}$ & Social Exclusion & $\begin{array}{l}\text { Classmates exclude a girl } \\
\text { because of her glasses. }\end{array}$ \\
\hline \multirow{14}{*}{$\begin{array}{l}\text { C. What should I do in } \\
\text { these situations? SIP } \\
\text { Steps } 3,4,5\end{array}$} & \multirow[t]{3}{*}{ Socio emotional game } & Provocation & $\begin{array}{l}\text { A boy takes a bicycle from } \\
\text { another child. }\end{array}$ \\
\hline & & Transgression (3) & A girl cuts a flower in a garden. \\
\hline & & Cooperation (2) & $\begin{array}{l}\text { Two boys play together with a } \\
\text { ball }\end{array}$ \\
\hline & \multirow[t]{4}{*}{ Pictures ("Feelings") } & Conflict (2) & Two boys fight for the same toy. \\
\hline & & Social Exclusion & $\begin{array}{l}\text { A girl is alone on a bench while } \\
\text { others play together. }\end{array}$ \\
\hline & & Transgression & $\begin{array}{l}\text { A boy takes chips in } \\
\text { supermarket when father said } \\
\text { that he could not. }\end{array}$ \\
\hline & & Prosocial & $\begin{array}{l}\text { Grandmother gives a gift to her } \\
\text { grandson. }\end{array}$ \\
\hline & \multirow[t]{6}{*}{ Cards Boxes } & Provocation & $\begin{array}{l}\text { One girl teases another because } \\
\text { of her socks. }\end{array}$ \\
\hline & & Social Exclusion & $\begin{array}{l}\text { A girl is alone and cries while a } \\
\text { boy plays with a game. }\end{array}$ \\
\hline & & Transgression & A baby boy throws his food. \\
\hline & & Ambiguous Situation & $\begin{array}{l}\text { A girl spills water on a drawing } \\
\text { accidently while she is watering } \\
\text { flowers. }\end{array}$ \\
\hline & & Cooperation & Two children play together. \\
\hline & & Prosocial & $\begin{array}{l}\text { A girl gives flowers to her } \\
\text { grandmother. }\end{array}$ \\
\hline & $\begin{array}{l}\text { Pictorial book } \\
\text { am I "Why } \\
\text { behaved?") }\end{array}$ & Transgression & $\begin{array}{l}\text { A boy is behaving badly (doing } \\
\text { stupid things). }\end{array}$ \\
\hline \multirow{4}{*}{$\begin{array}{ll}\text { D. } & \text { Are there other } \\
\text { possible responses? } \\
\text { SIP Steps } \mathbf{3}, \mathbf{4 , 5}\end{array}$} & \multirow[t]{3}{*}{$\begin{array}{l}\text { Videos (STEP-P; } \\
\text { Schultz et al., 2010) }\end{array}$} & Provocation (4) & $\begin{array}{l}\text { A girl throws a ball in another } \\
\text { girl's face. }\end{array}$ \\
\hline & & Social Exclusion (3) & A girl sits alone on a rock. \\
\hline & & Cooperation (2) & $\begin{array}{l}\text { A girl asks to play with other } \\
\text { children. }\end{array}$ \\
\hline & Cards Boxes & Provocation (2) & $\begin{array}{l}\text { A boy screams at another } \\
\text { because he wants his game. }\end{array}$ \\
\hline
\end{tabular}




\begin{tabular}{|c|c|c|c|}
\hline & & Social Exclusion (2) & $\begin{array}{l}\text { Three girls tease another girl } \\
\text { who is on her own. }\end{array}$ \\
\hline & & Cooperation & Children play music. \\
\hline & & Prosocial & A boy draws. \\
\hline & $\begin{array}{l}\text { Picture Book ("Lili } \\
\text { fights with her brother") }\end{array}$ & Conflict & $\begin{array}{l}\text { Lili fights with her brother for } \\
\text { various reasons. }\end{array}$ \\
\hline \multirow{10}{*}{$\begin{array}{l}\text { E. How to deal with } \\
\text { critical social } \\
\text { situations? } \\
\text { SIP Steps } 3,4,5\end{array}$} & \multirow[t]{4}{*}{$\begin{array}{l}\text { Videos (STEP-P, Schultz } \\
\text { et al., 2010) }\end{array}$} & Provocation (2) & $\begin{array}{l}\text { A boy gets water on another } \\
\text { boy's drawing. }\end{array}$ \\
\hline & & Conflict (2) & $\begin{array}{l}\text { A boy steals a ball from another } \\
\text { boy. }\end{array}$ \\
\hline & & Social Exclusion (3) & $\begin{array}{l}\text { A girl does not want to talk to } \\
\text { another girl. }\end{array}$ \\
\hline & & Frustration (3) & $\begin{array}{l}\text { A boy does not want to play } \\
\text { with a girl. }\end{array}$ \\
\hline & \multirow[t]{4}{*}{ Cards Boxes } & Provocation (2) & $\begin{array}{l}\text { A boy throws a girl's pencil on } \\
\text { the floor. }\end{array}$ \\
\hline & & Conflict & Two boys fight. \\
\hline & & Ambiguous Situation & $\begin{array}{l}\text { A boy accidentally breaks a } \\
\text { window by with his ball. }\end{array}$ \\
\hline & & Prosocial (2) & $\begin{array}{l}\text { A mother reads a book to her } \\
\text { daughter. }\end{array}$ \\
\hline & Game (“Problems") & Ambiguous Situation & $\begin{array}{l}\text { A girl on roller skates shoves an } \\
\text { old woman. }\end{array}$ \\
\hline & $\begin{array}{l}\text { Picture Book ("Lili } \\
\text { fights with her brother") }\end{array}$ & Conflict & $\begin{array}{l}\text { Lili fights with her brother for } \\
\text { various reasons. }\end{array}$ \\
\hline \multirow{5}{*}{$\begin{array}{l}\text { F. How to deal with } \\
\text { critical social } \\
\text { situations? } \\
\text { SIP Steps } 3,4,5\end{array}$} & \multirow[t]{3}{*}{$\begin{array}{l}\text { Videos (STEP-P, Schultz } \\
\text { et al., 2010) }\end{array}$} & Provocation (4) & $\begin{array}{l}\text { A girl shoves another girl on } \\
\text { purpose. }\end{array}$ \\
\hline & & Social Exclusion (2) & $\begin{array}{l}\text { One girl is on her own while the } \\
\text { other children are all talking } \\
\text { together. }\end{array}$ \\
\hline & & Frustration (2) & $\begin{array}{l}\text { Two girls do not want to let } \\
\text { another girl play with them. }\end{array}$ \\
\hline & Game (“Problems") & Conflict & $\begin{array}{l}\text { Parents are arguing with their } \\
\text { child. }\end{array}$ \\
\hline & $\begin{array}{l}\text { Picture Book ("Max } \\
\text { goes on a school trip") }\end{array}$ & Social Exclusion & $\begin{array}{l}\text { Max goes on a school trip but } \\
\text { his classmates do not play with } \\
\text { him. }\end{array}$ \\
\hline \multirow{5}{*}{$\begin{array}{ll}\text { G. } & \text { How could I deal with } \\
\text { social situations? } \\
\text { SIP Steps } 1,2,3,4,5\end{array}$} & \multirow{3}{*}{$\begin{array}{l}\text { Pictures ("They are } \\
\text { fighting") }\end{array}$} & Provocation & A boy pulls a girl's hair \\
\hline & & Conflict (2) & Two girls quarrel. \\
\hline & & Transgression & $\begin{array}{l}\text { A boy is naughty and his mother } \\
\text { punishes him. }\end{array}$ \\
\hline & Emotional Thermometer & $\begin{array}{l}\text { Child chooses among different critical } \\
\text { social situations and matches the } \\
\text { situation with a solution. }\end{array}$ & \\
\hline & $\begin{array}{l}\text { Picture Book ("Max } \\
\text { goes on school trip") }\end{array}$ & Social Exclusion & $\begin{array}{l}\text { Max goes on a school trip but } \\
\text { his classmates do not play with } \\
\text { him. }\end{array}$ \\
\hline \multirow{5}{*}{$\begin{array}{ll}\text { H. } & \text { Booster and } \\
\text { integrative session } \\
\text { SIP Steps 1, 2, 3, 4, } 5\end{array}$} & \multirow[t]{4}{*}{ Pictures } & Provocation & A boy breaks a glass. \\
\hline & & Conflict & A girl bites a boy's arm. \\
\hline & & Transgression (2) & A boy steals a game. \\
\hline & & Cooperation (2) & $\begin{array}{l}\text { A girl helps her mother to order } \\
\text { clothes. }\end{array}$ \\
\hline & $\begin{array}{l}\text { Picture Book (“Can I go } \\
\text { or not?") }\end{array}$ & Transgression & $\begin{array}{l}\text { A child considers whether to be } \\
\text { naughty. }\end{array}$ \\
\hline
\end{tabular}


Appendix C: "SIP program for children": objectives and techniques

\begin{tabular}{|c|c|c|}
\hline & Objectives & Techniques \\
\hline Transversal & $\begin{array}{l}\text { - Support the child's socio-emotional } \\
\text { development (understanding and regulation of } \\
\text { emotions) } \\
\text { - Understand social problem solving } \\
\text { - Understand social information processing, } \\
\text { notably abilities displayed in five steps: } \\
\circ \quad \text { encoding other people's social and } \\
\text { emotional cues, } \\
\circ \quad \text { interpretation of social and emotional cues, } \\
\circ \quad \text { clarification of goals, } \\
\circ \quad \text { response access, } \\
\circ \text { response decision. }\end{array}$ & $\begin{array}{l}\text { - Asking for children's explanation for each of } \\
\text { their responses } \\
\text { - Immediate and differentiated feedback as } \\
\text { reinforcer or correction, provided after each } \\
\text { response } \\
\text { - } \quad \begin{array}{l}\text { Explanation by the experimenter of the correct } \\
\text { response }\end{array} \\
\text { - Explanation by the experimenter of the general } \\
\text { principle guiding the good answers } \\
\text { - Conversations and use of terms related to critical } \\
\text { social situations } \\
\text { Discussions arising from questions about critical } \\
\text { social situations } \\
\text { Connections with real life events }\end{array}$ \\
\hline $\begin{array}{l}\text { Related to } \\
\text { SIP steps }\end{array}$ & 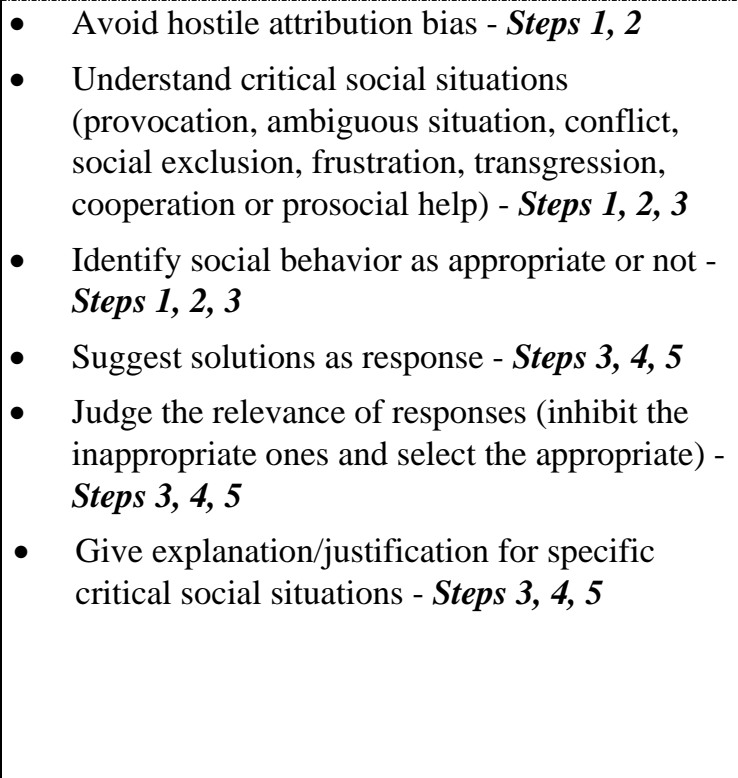 & $\begin{array}{l}\text { - Semi-open questions about critical social } \\
\text { situations } \\
\text { O What happened? Is it good or bad? -Step } 1 \\
\text { Did it happen on purpose or accidentally? - } \\
\text { Step } 2 \\
\text { What would you do in such situation? - Step } \\
\quad 3 \\
\text { Why is it good or bad? Could he do/say } \\
\text { something else? - Step } 4 \\
\text { Is this solution a good response? - Step } 5 \\
\text { Identification of social and emotional cues - } \\
\text { Steps } 1,2 \\
\text { Identification of alternative solutions to critical } \\
\text { social situations - Steps } 3,4 \\
\text { Selection and activation of the best solution in } \\
\text { relation to critical social situations - Steps } 3,4,5\end{array}$ \\
\hline
\end{tabular}

\section{Copyrights}

Copyright for this article is retained by the author(s), with first publication rights granted to the journal.

This is an open-access article distributed under the terms and conditions of the Creative Commons Attribution license which permits unrestricted use, distribution, and reproduction in any medium, provided the original work is properly cited. 